Journal Plus Education, ISSN: 1842-077X, E-ISSN (online) 2068-1151 Vol XIX (2018), No. 1. pp. 176-184

\title{
DIFFERENCES IN MOTOR SKILS BETWEEN PRESCHOOL BOYS AND GIRLS
}

\author{
Vladan PELEMIŠ, Ph.D. Faculty of Teacher Education, University of \\ Belgrade, Serbia \\ Slobodan PAVLOVIĆ, Ph.D. Faculty of Teacher Education, University \\ of Kragujevac, Serbia \\ Zdravko ANIČIĆ, MSc. Faculty of Sport and Physical Education, \\ University of Belgrade, Serbia \\ vladan.pelemis@uf.bg.ac.rs
}

\begin{abstract}
The study was conducted on a sample of 50 boys and 44 girls aged 6 and 7 from Novi Sad. Seven motor skills tests were conducted. Multivariate (MANOVA) analysis of variance has revealed statistically significant differences in motor abilities between boys and girls $(F=2.60 ; P=0.02)$. Separate analysis has concluded that those differences exist in the motor-ability factor for the assessment of the whole body coordination - Polygon backwards $(p=0.02)$ and the lower-limb explosive power evaluation - A $20 \mathrm{~m}$ sprint test froma starting position $(p=0.04)$ in favor of boys in both cases, as well as the the factor for the functional synegry and the regulation of muscle tone manifested through the variable Wide-angle seated forward bend $(p=0.04)$ in favor of girls.
\end{abstract}

Key words: motor skills; preschool children; difference;, sexual dimorphism;

\section{Introduction}

The problem of assessing the motor skills is especially evident in preschool age. The motor skills at this age are not yet differentiated, and there is often a question of the validity and usefulness of some tests for the assessment of certain (hypothetical) dimensions of motoric status. Another problem is in the protocol of measurement of the motor abilities. The measurement of the motor abilities regularly includes maximum involvement of the respondents. At this age, it is virtually impossible to reach it as children are not aware of the need to achieve maximum energy engagement, which is the basis for the precise determination of the state in certain motor abilities (Clark et al., 2016).

The motor abilities in the preschool age are not yet fully defined; this period is very important in their development especially the development of the basic (general) motor abilities. When mastering motor movement tasks 
that seek to assess a child's motors, what is manifested is exactly the general effect of different abilities and skills of the child. Practically, it seems that children with their overall motor knowledge make the realization of the motor movement tasks. Therefore, many experiences further confirm that physical exercise between the ages of four and seven should be based on creating the best possible basis; that is a practical preparation of the best possible basis for the future development of specific motor abilities.

Difficulties in proper determining of motor skills status of a child in this period are those when the motor tests are executed, individual motor abilities do not show isolated as in adults, so it is very difficult to determine which function those motor abilities serve. Using various motor tests in different age groups different motor abilities are estimated. For example: High jump test in adults estimates explosive power, while testing children is considered to be a coordination assessment. Another example of this can be found in the Hand tapping test, which assesses the frequency of alternative hand movements in adults. It seems that this motor test conducted with children can assess their ability to coordinate (Matic, 2008).

The mechanism for movement structuring can also be called the general factor of coordination. This, among other things, depends on how fast a person can form his/her own motor programs, i.e. how fast he/she can adopt new movement structures.

According to Bala (1981) who was examining the structure of motor skills in children aged 6-10, the existence of hypothetical motor dimensions was not confirmed. Based on the research results the author concludes that it can, at least hypothetically, be stated that the motor ability in the examined children is general in nature and that it can be understood as the "motor intelligence." Considering the obtained results, it is pointed out that the development of general motor abilities in children should be toward more comprehensive development of a general motor ability, and the use of specific motor activities by the age of 12 can only be seen as part of the development of the general motor ability at a higher level.

Motor abilities are demonstrated in such a way that one ability compensates for another, so that a child manifests his/her complex motor ability in a variety of situations and tasks (Nićin, 2000). Similar results were obtained by Turek (2000) based on a research with children aged 7-10 of Slovak population using the Eurofit test battery. The author concludes that the period of early school age is characterized by significant variability and the motors which are still not defined.

Using the transverse measurements Pavlovic (1984) monitored the condition of the physical abilities of the population of Vojvodina. The research focused on monitoring the annual increment in the results achieved in individual motor abilities. The highest annual increment in the early 
school age children was found in the following tests: Long jump (for girls), and Three ball slalom drill (boys and girls). Comparing with the research that was conducted by the same author in the 1980s, the decline was noted in physical abilities. Therefore, based on these indicators and the impacts of today's lifestyle of young people (sitting more with less physical movement, increased levels of hypokinesia and sedentary lifestyle), it can only be assumed how much the motor abilities of children have decreased by now compared with that period.

The research on a representative sample of young people $(10,713$ boys and 10,979 girls) conducted by Moravec and Sedlacek (1990), in which they observed the differences in the dynamics of the development of certain motor abilities showed that there are some differences in the pace of the development of certain motor abilities. The authors point out that the age of $7-8$ is a period very suitable for the development of motor abilities, whereas the age of 8-9 is a period for the endurance development. In early school age boys, it is recommended to work on the development of coordination.

The problem of the research was related to the analysis of the quantitative characteristics of motor abilities of boys and girls of preschool age. The primary objective of this research was to determine whether there were statistically significant differences in motor abilities between boys and girls of the preschool age 6 - 7 from Belgrade.

\section{Method}

For the purpose of this research the experiment method that was used was transversal, which means that there was only one measurement conducted on the whole sample of preschool children.

The sample of subjects for the research was derived from a population of preschool children from Belgrade. Measurement of the motor abilities was performed on a sample of 94 subjects, divided into two subgroups, as follows: 50 boys and 44 girls aged 6 - 7 from Belgrade. All subjects at the time of measurement of motor abilities attended a preschool institution in Belgrade.

For the assessment of the motor abilities in preschool children standardized motor tests, based on the model of Bala, Stojanovic, \& Stojanovic (2007), were used and the following battery of tests was applied:

I For the assessment of the factors of structuring of movement:

1) Polygon backwards (0.1 s),

2) Standing long jump (cm),

3) $20 \mathrm{~m}$ run from a standing start $(0.1 \mathrm{~s})$,

II For the assessment of the functional synergy factors and the regulation of muscle tone:

4) Hand tapping (freq.), 
5) Wide-angled seated forward bend ( $\mathrm{cm})$,

III For the assessment of the duration factor of motor unit excitability:

6) Body lifting in $60 \mathrm{~s}$ (freq.),

7) Endurance in pull-ups (0.1 s).

\section{Results and Discussion}

In accordance with the applied methodology of kinesiology research first the basic descriptive statistics of the motor variables were identified, together with the values of skewness and kurtosis. The results are presented for boys and girls separately.

Table 1. DESCRIPTIVE STATISTICS OF MOTOR VARIABLES

\begin{tabular}{|c|c|c|c|c|c|c|c|}
\hline Variable & Group & $\mathrm{AM}$ & $\mathrm{S}$ & MIN & MAX & Sk & Kurt \\
\hline \multirow{2}{*}{ Polygon backwards $(0,1 \mathrm{~s})$} & Boys & 179.94 & 49.38 & 103 & 318 & 0.85 & 0.61 \\
\hline & Girls & 210.02 & 75.54 & 115 & 522 & 1.79 & 5.53 \\
\hline \multirow{2}{*}{ Standing long jump (cm) } & Boys & 128.06 & 17.88 & 85 & 175 & 0.17 & 0.66 \\
\hline & Girls & 126.55 & 23.40 & 75 & 170 & 0.05 & -0.87 \\
\hline \multirow{2}{*}{$20 \mathrm{~m}$ run from a standing start $(0,1 \mathrm{~s})$} & Boys & 48.18 & 4.61 & 39 & 58 & 0.29 & -0.61 \\
\hline & Girls & 50.36 & 5.73 & 39 & 66 & 0.63 & 0.49 \\
\hline \multirow{2}{*}{ Hand tapping (freq.) } & Boys & 18.30 & 3.87 & 10 & 29 & 0.13 & 0.18 \\
\hline & Girls & 18.34 & 3.95 & 4 & 26 & -1.07 & 2.98 \\
\hline \multirow{2}{*}{ Wide-angled seated forward bend $(\mathrm{cm})$} & Boys & 41.30 & 5.19 & 30 & 53 & 0.08 & 0.27 \\
\hline & Girls & 43.48 & 5.04 & 31 & 53 & -0.20 & 0.07 \\
\hline \multirow{2}{*}{ Body lifting in $60 \mathrm{~s}$ (freq.) } & Boys & 19.84 & 8.66 & 0 & 38 & -0.03 & -0.56 \\
\hline & Girls & 22.27 & 9.43 & 0 & 42 & -0.46 & 0.32 \\
\hline \multirow{2}{*}{ Endurance in pull-ups $(0,1 \mathrm{~s})$} & Boys & 159.18 & 153.17 & 0 & 770 & 1.98 & 4.62 \\
\hline & Girls & 158.80 & 100.88 & 0 & 470 & 0.93 & 1.47 \\
\hline
\end{tabular}

Legend: AM - arithmetic mean, $S$ - standard deviation, $M I N$ - minimum measurement result recorded, MAX-maximum measurement result recorded; Sk - skewness (inclination of distribution of results); Kurt kurtosis (elongation distribution of the results).

Taking into account the values of the descriptive statistics for the motor variables in Table 1 it can be stated that the boys were homogeneous in the variable Endurance in pull-ups, while the girls were homogeneous in the variables for the assessment of coordination Polygon backwards and the variable for assessment of the frequency of alternative hand movements, Hand tapping. In other motor variables heterogeneity of the groups was expressed that is conditioned by different levels of the motor abilities and social conditions of the environments in which the children live.

The extremely positive asymmetric distribution of the results of the variable for the assessment of the static strength of arms and shoulders in 
boys and Polygon backwards variable in girls, indicates that most of the results are in the low-value area. This fact was contributed to by the lower arm muscle strength, a uniform level of the muscle strength of arms and shoulders in this development period in boys, and a distinct and uniform level of coordination in girls in this sample of preschool children.

In the variable for assessing the factors of functional synergy and tone regulation, which is manifested through the Hand tapping variable, it is observed that most of the girls' results were in the zone of higher-value area. The uniform level of the muscle strength of arms and the velocity of movement responsible for this motion of the body parts in space caused the appearance of homogeneity of the results in the aforementioned motor variable.

Table 2. KOLMOGOROV-SMIRNOV TEST FOR MOTOR VARIABLES AMONG

\section{SUBJECTS OF DIFFERENT SEXES}

\begin{tabular}{lllll}
\hline Variable & Group & K-S & $\mathrm{p}$ & MEA \\
\hline \multirow{2}{*}{ Polygon backwards } & Boys & 0.96 & 0.32 & 0.136 \\
& Girls & 0.79 & 0.57 & 0.118 \\
Standing long jump & Dečaci & 0.87 & 0.43 & 0.124 \\
& Boys & 0.88 & 0.42 & 0.133 \\
20 m run from a standing start & Girls & 1.00 & 0.27 & 0.142 \\
Hand tapping & Boys & 0.91 & 0.38 & 0.138 \\
& Girls & 0.63 & 0.82 & 0.089 \\
Forward bend in sitting with stretched legs & Boys & 1.04 & 0.23 & 0.157 \\
& Girls & 0.79 & 0.56 & 0.112 \\
Body lifting in 60 s & Boys & 0.63 & 0.82 & 0.095 \\
Endurance in pull-ups & Girls & 0.72 & 0.68 & 0.101 \\
& Boys & 0.87 & 0.43 & 0.132 \\
\end{tabular}

Legend: KS - Kilmogorov - Smirnov Z coefficient, $p$ - level of statistical significance of the Kolmogorov - Smirnov Z coefficient; MEA - maximum extreme difference between the obtained and the expected distribution.

Testing of the normal distribution of the motor variables for boys and girls of preschool age shown in Table 2 indicates that there are no statistically significant deviations of the obtained distribution of the motor variables from the normal (theoretical) distribution ( $p>0.01$ ). Maximum extreme differences between the tested and the expected distributions were not greater than $0.21 \mathrm{z}$-scores. 
Journal Plus Education, ISSN: 1842-077X, E-ISSN (online) 2068-1151 Vol XIX (2018), No. 1. pp. 176-184

Table 3. DIFFERENCES BETWEEN THE SUBJECTS OF DIFFERENT SEXES IN

MOTOR VARIABLES

\begin{tabular}{llllll}
\hline Sex & Variable & F & p & F & P \\
\hline & Polygon backwards & 5.34 & $\mathbf{0 . 0 2}$ & & \\
& Standing long jump & 0.13 & 0.72 & & \\
Boys & 20 m run from a standing start & 4.18 & $\mathbf{0 . 0 4}$ & \multirow{2}{*}{2.60} & $\mathbf{0 . 0 2}$ \\
Girls & Hand tapping & 0.01 & 0.96 & & \\
& Wide-angled seated forward bend & 4.23 & $\mathbf{0 . 0 4}$ & & \\
& Body lifting in 60 s & 1.70 & 0.20 & & \\
\hline
\end{tabular}

Legend: $f$ - univariate $\mathrm{f}$ test, $\mathrm{p}$ - level of statistical significance of $\mathrm{f}$ test, $\mathrm{F}$ - multivariate Wilks $\mathrm{F}$ test, $\mathrm{P}$ - statistical significance of multivariate $\mathrm{F}$ test.

By inspecting the values of the multivariate Wilks $F$ test, it can be concluded that there is a statistically significant difference $(P=0.00)$ between the subjects of different sexes in terms of their motor skills at the value of $F=2.60$ in the given sample. With the separate analysis of each motor variable tested, it is concluded that these differences are present in the following variables: Polygon backwards $(\mathrm{p}=0.02), 20 \mathrm{~m}$ run from a standing start $(\mathrm{p}=0.04)$, in favor of boys, and the variable of Wide-angled seated forward bend $(\mathrm{p}=0.04)$ in favor of girls.

Better values of the hypothetical motor factors for coordination manifested through the variable of Polygon backwards in favor of boys can be linked to their current interests during the preschool age. Boys are more active than girls, and with their daily activities they "explore" and "learn about" the things and the world around them (Pavlović, Marinković i Bojović, 2014). With such an approach, their motor abilities are raised to a higher level, best manifested through the coordination of movement and coordination of the entire body as was the case in this research. The boys' coordination was at a higher level than the girls' who were of the same age. This is a direct consequence of the boys' activities, which could be manifested onto the presence of statistically significant differences in the variable of $20 \mathrm{~m}$ run from a standing start in their favor.

As children get older, the growth influences the cortex on the subcortical structures of the brain, and the movement control is greater as well as the behavior sensefulness. A child's motor behavior will be easier to improve, he/she will more easily build new movements and exercises if he/she is more active, i.e. under the influence of controlled and systematically guided kinesiology treatment. Due to such knowledge and the fact that the efferent part of the nervous system has not been fully developed 
in children of preschool age, it is necessary to start physical training in time, so that children can be as healthy as possible and can develop properly, and should not, in their motor development, fall behind other children who are included in the kinesiology treatment.

If we add these findings to the research of Bala, Djordjic, Popovic, \& Sabo (2006), which states that the test for the explosive leg power assessment - Standing long jump in preschool children is more a coordination assessment test rather than explosive power test, since children need to connect more motor actions in one unit, so that the result would be better, the result is perhaps logical. The coordination in preschool age children, in addition to physiologic maturation of the body, depends on the activities of the child, on working with him/her in the field of motor abilities as well as on environmental factors.

To this fact we can also add the indicator that the afferent part of the nervous system, which carries impulses from the periphery to the CNS, matures between the age of 6-7 both in boys and girls. The afferent part of the nervous system which carries impulses from the CNS to the periphery, organs, tissues and muscles, finally matures at the age of 23-25. Due to the structural - functional maturation of the cortex and taking over a dominant role in the cortico-subcortical interaction, it is especially important for the motor development of a child, his/her behaviour and response in newly emergent situations (coordination of a child). Therefore, it is necessary to include children in physical exercise as early as possible and enrich their motors, as later in life children cannot compensate for how much they lost in preschool age. This research confirmed that the boys had significantly better results than the girls of the same age in the motor coordination assessment tests and sprint test.

The mere fact that girls have differently placed pelvis, that is wider due to a biological need for childbirth (pubic symphyses), was reflected in the better results of the girls in the hypothetical motor factor for the flexibility which was tested through the variable Wide-angled seated forward bend. The smaller angle of the femoral head in the acetabulum fossa in girls allows for greater muscles stretching on the back of the thigh resulting in a greater range of motions in the hip joint. Greater stretching of the muscles gives better results in this flexibility assessment test. Based on the results we may conclude that the differences arise in favour of the girls due to different femoral attachment to the pelvic cup, as well as different pelvic width in girls compared with boys of the same age. 
Journal Plus Education, ISSN: 1842-077X, E-ISSN (online) 2068-1151 Vol XIX (2018), No. 1. pp. 176-184

\section{Conclusion}

This research confirms the presence of statistically significant differences according to the sex of the subjects in the area of motor abilities. With the separate analysis of each motor variable tested, it is concluded that these differences are present in the following variables: Polygon backwards, $20 \mathrm{~m}$ run from a standing start, in favour of boys and Wide-angled seated forward bend in favour of girls.

Generally, it can be concluded that the boys had significantly better coordination (estimated with the tests Polygon backwards and $20 \mathrm{~m}$ run from a standing start). It may be surprising that the last two variables are used to assess the coordination of children, rather than running speed and explosive leg power, as it is the case with adults. Because of the undifferentiated primary motor abilities in children of the analysed age, these variables behave better as indicators for the coordination assessment, since suitable motor tests primarily require coordinated execution of necessary movements and motion, which belongs to the domain of the information component of the motor abilities in children, and only after successfully overcoming the overall structure of the task, the size of the energy component which a child should in both cases manifest with maximal excitation of the motor units can be detected.

If the previous results are analysed from the aspect of neurophysiological mechanisms defined in the research with older children and adolescents (eg. Kurelić et al., 1975), and even better in the elderly (eg. Gredelj et al., 1975), it can be concluded that the boys have a better expressed functioning of the movement structure mechanism, which is manifested through motor abilities: body coordination (Standing long jump and $20 \mathrm{~m} \mathrm{run}$ ), the reorganization of the stereotyped movements (Polygon backwards), and the mechanism for the regulation of duration of excitation of the motor units (Endurance in pull-ups). There is a significantly better functioning of the mechanism for synergistic regulation and regulation of muscle tone in girls. The part that relates to the regulation of the tone (Wideangled seated forward bend) is consistently and significantly more pronounced in girls due to a different constitution of the pelvis, femoral head, which is placed under a smaller angle to the acetabulum fossa, so the execution of the movement in the hip joint is easier.

\section{References}

Bala, G. (1981). Struktura i razvoj morfolških i motoričkih dimenzija dece SAP Vojvodine. Novi Sad: Fakultet fizičke kulture. 
Journal Plus Education, ISSN: 1842-077X, E-ISSN (online) 2068-1151 Vol XIX (2018), No. 1. pp. 176-184

Bala, G. (2004). Kvantitativne razlike osnovnih antropometrijskih karakteristika i motoričkih sposobnosti dečaka i devojčica u predškolskom uzrastu. Glasnik Antropološkog društva Jugoslavije, 39, 219-227.

Bala, G., Stojanović, M. i Stojanović, M. (2007). Merenje i definisanje motoričkih sposobnosti dece. Novi Sad: Fakultet sporta i fizičkog vaspitanja.

Clark, C. A. C., Chevalier, N., Nelson, J. M., James, T. D., Garza, J. P., Choi, H. J., \& Espy, K. A. (2016). Executive Control In Early Childhood. Monographs Of The Society For Research In Child Development, 81, (4), 17-34.

Matić, R. (2008). Relacije motoričkih sposobnosti, morfoloških i socioekonomskih karakteristika dece mlađeg školskog uzrasta. Magistarski rad, Novi Sad: Fakultet sporta i fizičkog vaspitanja.

Moravec, R., Sedlaček, J. (1990). Razlike u dinamici razvoja pojedinih motoričkih sposobnosti. Fizička kultura, 44-45 (4), 256-258.

Nićin, Đ. (2000). Antropomotorika-teorija. Novi Sad: Fakultet fizičke kulture.

Pavlović, Đ. (1984). Fizička razvijenost $i$ fizičke sposobnosti stavnovnika SAP Vojvodine stanje 1984. godine. Novi Sad: Zavod za fizičku kulturu Vojvodine.

Pavlović, S., Marinković, D. i Bojović, Ž. (2014). Efikasnost primene poligona na razvoj koordinacije u nastavi fizičkog vaspitanja. Nastava $i$ vaspitanje, 2, 299-311.

Popović, B. (2006). Trend razvoja antropometrijskih karakteristika dece uzrasta 4-11 godina. Zbornik sažetaka 46 kongresa Antropološkog društva Jugoslavije, 128, Banja Junaković - Apatin.

Sabo, E. (2006). Razlike između dečaka i devojčica u antropometrijskim karakteristikama prilikom upisa u osnovnu školu. Pedagoška stvarnost, 1,(vol. 3-4), 3

Turek, M. (2000). Parcijalna struktura motoričkog učinka dece od sedam do deset godina. Zbornik radova drugi i treći simpozijum sa međunarodnim učešćem. Efekti različitih modela nastave fizičkog vaspitanja na psihosomatski status dece $i$ omladine (str. 56-59). Novi Sad: Fakultet fizičke kulture. 